\title{
Deoxyribonucleic Acid Homology Among Strains of Rhizobium trifolii and Related Species
}

\author{
B. D. W. JARVIS,' A. G. DICK,' AND R. M. GREENWOOD ${ }^{2}$ \\ Department of Microbiology and Genetics, Massey University, ${ }^{1}$ and Applied Biochemistry Division, \\ Department of Scientific and Industrial Research, ${ }^{2}$ Palmerston North, New Zealand
}

Deoxyribonucleic acid homologies were determined among 27 strains of $R \mathrm{hi}$ zobium trifolii, 4 strains of Rhizobium leguminosarum, and 4 strains of Rhizobium phaseoli. Results from related strains indicated that deoxyribonucleic acid homologies correlate with serological relationships and that the ability to form nodules on legume roots can be lost without a detectable change in homology with an independent reference strain. All rhizobia which effectively nodulated Trifolium repens, Trifolium subterraneum, Trifolium ambiguum, and Vicia hirsuta formed one population with an average relatedness of $70 \%$ (range, 49 to $94 \%$ ) and a $\Delta T_{m(e)}$ of 0.0 to $11.8^{\circ} \mathrm{C}$ with respect to reference strains capable of nodulating the first two clover species. Two strains from African Trifolium species and two strains from a northern Asiatic species were less closely related. The average relatedness of strains from Phaseolus vulgaris to clover rhizobia was $46 \%$ (range, 37 to $50 \%$ ), and the $\Delta \mathrm{T}_{m(e)}$ was 6.5 to $11.8^{\circ} \mathrm{C}$. Taxonomic revisions consistent with these observations are discussed. It is proposed that $R$. trifolii and $R$. leguminosarum should be combined under the name which has priority, Rhizobium leguminosarum Frank. Within this species various biovars should be designated according to plant specificity. $R$. phaseoli should be retained at present as a separate species and examined in more detail. The results are discussed in relation to proposed genetic bases for plant specificity.

The bacteria which form nodules on the roots of leguminous plants comprise the genus Rhizobium (22). Rhizobia have long been classified and named according to the specific plant or group of plants which they can nodulate $(12,22)$. The plant hosts comprise a cross-inoculation group and harbor symbionts which nodulate only plants in the group. This classification is unsatisfactory for several reasons. Many legume hosts are not included in the six cross-inoculation groups which define the recognized species. Cross-inoculation groups are not mutually exclusive, and isolation of bacteria which nodulate plants in more than one group is a common event $(10,39)$. Rhizobia readily lose their ability to effectively nodulate specific legumes $(5,23)$, and then their identity as rhizobia is dependent on knowledge of their earlier nodulating capability. Graham (16) has reviewed the limitations of the classification in Bergey's Manual of Determinative Bacteriology (22). Several groups have suggested that infectivity and effectiveness may be plasmid-borne characters $(11,18,21,30)$, and it seems likely that this will be demonstrated in the near future. Cross-inoculation groupings would then be untenable as a basis for classifying root nodule bacteria.

Several alternative classifications have been proposed. Norris (27) examined 717 strains of bacteria from 278 species of legumes and concluded that they could be classified into two groups: those which grew rapidly and formed acid on laboratory media and those which grew slowly and produced a neutral or alkaline reaction. Measurements of overall phenotypic sisiilarity have been reported by Graham (15), 'tMannetje (33), Moffet and Colwell (25), and White (38). These workers divided rhizobia into two clusters which corresponded to the fast and slow groups proposed by Norris (27). The fastgrowing species Rhizobium leguminosarum, Rhizobium phaseoli, and Rhizobium trifolii were grouped together as one species, and a relationship between this species and strains of Agrobacterium was demonstrated $(15,25)$. Rhizobium meliloti was retained as a separate, rather homogenous species within the cluster of fast-growing rhizobia. The second cluster contained Rhizobium japonicum and Rhizobium lupini and was distinguished from the first at species $(33)$ or generic level $(15,25)$. However, the small range of rhizobia examined by phenetic methods does not represent the diversity of nodulated legumes; consequently, the number of phenotypically distinct groups of legume root nodule bacteria remains uncertain.

Heberlein et al. (17) used DNA reassociation to confirm the relationship between "fast-grow- 
ing acid-producing" rhizobia and Agrobacterium, and Gibbons and Gregory (13) examined 20 strains representing the six named species of Rhizobium and the genus Agrobacterium. They found genetic relationships in broad agreement with the phenotypic studies referred to above. Deoxyribonucleic acid (DNA) hybridization was also used to confirm the relationship between root nodule bacteria from legumes indigenous to New Zealand and strains designated as $R$. lupini (19). None of these reports has concerned DNA from a large enough group of strains to indicate the genetic diversity to be expected among rhizobia from the same cross-inoculation group.

In our research, DNA reassociation techniques were used to determine the genetic variation among bacteria which nodulate plants in the genus Trifolium. All strains studied were designated $R$. trifolii, except a few strains designated $R$. leguminosarum and $R$. phaseoli which were also included for comparative purposes.

\section{MATERIALS AND METHODS}

Bacterial strains. The bacterial strains included in this investigation are listed in Table 1 by taxonomic species in alphabetic order of their country of origin. To ensure that pure cultures were used, all strains were plated out, and single, well-separated colonies were taken. Later tests showed that this had led to the selection of several variants in nodulation and effectiveness. Stock cultures were maintained on yeast extract mannitol (YM) agar slopes at $5^{\circ} \mathrm{C}$ and also as freeze-dried suspensions.

Media and cultivation. Cells were grown on YM medium (36). Dried yeast extract ( $0.4 \mathrm{~g} /$ liter; Difco Laboratories) was substituted for yeast water, and agar (1.45\%; Davis Gelatine N.Z. Ltd.) was added when solid medium was required. Before each use, stock cultures were streaked on YM agar and brain heart infusion agar and incubated at $30^{\circ} \mathrm{C}$ for 3 to 4 days to ensure purity. Mass cultures for DNA preparation were obtained by transferring a well-isolated colony from YM agar to YM liquid medium $(100 \mathrm{ml})$ and incubating on a gyratory shaker for 2 days at $30^{\circ} \mathrm{C}$. This culture was then used to inoculate 2 liters of YM medium, which was incubated for 2 days at $30^{\circ} \mathrm{C}$, by which time it had reached the stationary phase of growth. When the cells were harvested, the cultures were again streaked onto YM and brain heart infusion agar plates and examined microscopically to detect contaminants. Radioactively labeled cells were prepared in the same manner, but dipotassium hydrogen phosphate was omitted from the media, and $20 \mathrm{mCi}$ of ${ }^{32} \mathrm{P}$ (as a sterile solution of orthophosphate in dilute hydrochloric acid) was added to the final culture (900 $\mathrm{ml})$ after $4 \mathrm{~h}$ of incubation at $30^{\circ} \mathrm{C}$.

Nodulation and effectiveness. All $R$. trifolii strains were tested for nodulating ability and effectiveness on white clover (Trifolium repens) and subterranean clover (Trifolium subterraneum cv. Tallarook). A few strains were also tested on $T$. subterraneum cv. Woogenellup. The method of Moustafa and
Greenwood (26) was used. Sterile pregerminated seeds were planted in large test tubes containing nitrogenfree nutrient agar. Two tubes, each containing two subterranean or three white clover plants, were inoculated with each rhizobial strain. The fresh weight of the tops produced was compared with that of control uninoculated plants and that of plants inoculated with strain TA1, which is known to be effective on white and subterranean clovers. Strains were rated as effective if the weight of the tops was not significantly different from that of plants inoculated with strain TA1, as moderately effective or slightly effective if the weights were significantly different at the $1 \%$ level from the weight of TA1 tops and from one another, and as ineffective if nodules were produced but the top weight was not significantly different from that of the uninoculated controls. Strains not giving nodules were given a rating of zero.

Tests were also made with Trifolium ambiguum, Trifolium semipilosum, and Trifolium africanum, using the corresponding $R$. trifolii strains. The $R$. leguminosarum strains were tested on Vicia hirsuta and subterranean and white clovers, and the $R$. phaseoli strains were tested on Phaseolus vulgaris.

Preparation of unlabeled DNA. Unlabeled DNA was prepared by the method of Brenner et al. (3), except that ethanol replaced 2-ethoxyethanol in the final purification steps. The purity of this DNA was assessed from absorption spectra at wavelengths between 210 and $300 \mathrm{~nm}$, and spectral ratios at 258 versus $230 \mathrm{~nm}$ and 258 versus $280 \mathrm{~nm}$ of greater than 1.8 were regarded as satisfactory.

DNA solutions $(5.0 \mathrm{ml})$ in deionized water were sheared by sonication for $75 \mathrm{~s}$ at 0 to $5^{\circ} \mathrm{C}$ with a 100 W ultrasonic disintegrator (Measuring \& Scientific Equipment, Ltd., London, England) fitted with a 19mm diameter probe and tuned for maximum output. Under these conditions, alkaline sucrose gradient centrifugation (1) indicated that the average molecular weight of single-stranded fragments was $2.3 \times 10^{5}$. We found that the molecular weight was largely independent of DNA concentration between 82 and $650 \mu \mathrm{g} /$ $\mathrm{ml}$, a range which included all of our DNA preparations. After sonication, DNA solutions were made 0.28 $M$ with respect to sodium phosphate buffer $(\mathrm{PB})(\mathrm{pH}$ 6.8) and were stored at $-20^{\circ} \mathrm{C}$.

Preparation of [ $\left.{ }^{32} \mathrm{P}\right] \mathrm{DNA}$. DNA labeled with ${ }^{32} \mathrm{P}$ was prepared by a modification of the hydroxyapatite (HA)-urea method (6). A cell suspension was diluted 1:50 in a lysing solution (3) to which the following were added: $50 \mu \mathrm{g}$ of pronase (Calbiochem, San Diego, Calif.) or protease (type VI; Sigma Chemical Co., St. Louis, Mo.) per $\mathrm{ml} ; 50 \mu \mathrm{g}$ of pancreatic ribonuclease (Sigma) per ml; and $10 \mathrm{mg}$ of sodium lauryl sulfate per ml. Ribonuclease was incubated at $90^{\circ} \mathrm{C}$ for $10 \mathrm{~min}$ before use. After $2 \mathrm{~h}$ at $37^{\circ} \mathrm{C}, 25 \mu \mathrm{g}$ of pronase per $\mathrm{ml}$ and $25 \mu \mathrm{g}$ of ribonuclease per $\mathrm{ml}$ were added, and the sodium lauryl sulfate concentration was increased to $15 \mathrm{mg} / \mathrm{ml}$. After an additional $1 \mathrm{~h}$ at $37^{\circ} \mathrm{C}$, an equal volume of phenol saturated with water containing tris(hydroxymethyl)aminomethane buffer, $\mathrm{pH}$ 8.0, was added to the lysed cell suspension. The mixture was shaken vigorously to obtain a uniform suspension and centrifuged to separate the phases. The aqueous phase was quantitatively recovered and was made $0.14 \mathrm{M}$ $\mathrm{PB}, \mathrm{pH}$ 6.8. Solid urea was then added to make the 
solution $8.0 \mathrm{M}$, and the mixture was stirred until the urea dissolved (5 to $10 \mathrm{~min}$ ).

HA (Bio-Rad Laboratories, Richmond, Calif.) was prepared in $0.0014 \mathrm{M} \mathrm{PB}$ according to the instructions of the manufacturer. The HA suspension $(40 \mathrm{ml})$ was washed once on a centrifuge $(6,000 \times g, 2 \mathrm{~min})$ with 8.0 M urea in 0.14 M PB, and the supernatant was discarded. The crude DNA preparation was added, the washed HA was resuspended in it, and then the components were separated by centrifugation. The supernatant containing protein and ribonucleic acid was discarded and replaced with $100 \mathrm{ml}$ of $8.0 \mathrm{M}$ urea in $0.14 \mathrm{M}$ PB. In this way, HA and bound DNA were washed 10 times on the centrifuge. Urea was removed by washing the $\mathrm{HA}$ four times with $100 \mathrm{ml}$ of $0.014 \mathrm{M}$ PB. Finally, the HA was resuspended in $20 \mathrm{ml}$ of buffer, pelleted, and washed with $10 \mathrm{ml}$ of $0.66 \mathrm{M} \mathrm{PB}$ and then with four additional $10-\mathrm{ml}$ washes with 0.4 $M$ PB. Most of the DNA was contained in the first two fractions, and these were dialyzed twice for $2 \mathrm{~h}$ in 2 liters of $0.14 \mathrm{M}$ PB. The product was sheared by sonication for $56 \mathrm{~s}$, denatured in a boiling water bath for $10 \mathrm{~min}$, and eluted from an $\mathrm{HA}$ column at $60^{\circ} \mathrm{C}$ with $0.14 \mathrm{M}$ PB to decrease nonspecific binding to $\mathrm{HA}$ (3). DNA was preserved by the addition of a drop of chloroform if preparation was interrupted overnight. The finished preparation was stored at $-20^{\circ} \mathrm{C}$.

DNA reassociation. Tubes containing $0.1 \mu \mathrm{g}$ of labeled reference DNA (specific activity, 30,000 to $50,000 \mathrm{cpm} / \mu \mathrm{g}$ ) and $150 \mu \mathrm{g}$ of unlabeled DNA in $1 \mathrm{ml}$ of $0.28 \mathrm{M} \mathrm{PB}$ were placed in boiling water for $10 \mathrm{~min}$, chilled rapidly in an ice bucket, and held at $0^{\circ} \mathrm{C}$ until incubation was begun. Samples were reassociated at 65 or $80^{\circ} \mathrm{C}$ for $40 \mathrm{~h}$ and then held at $0^{\circ} \mathrm{C}$ until tested.

Reassociated double-stranded DNA and singlestranded DNA were separated by batchwise elution from HA with PB of appropriate molarity $(4,19)$. The buffer concentration required to elute single-stranded DNA completely without displacing double-stranded DNA is critical and usually lies between 0.11 and 0.13 M PB. It must be determined separately for each batch of HA. Eluants were collected in scintillation vials and assayed by Cerenkov counting at tritium settings in a scintillation counter. Counts eluted by 0.4 $\mathrm{M}$ PB expressed as a percentage of the total counts recovered indicated the percentage of hybrid doublestranded DNA. Relative hybridization values were obtained by adjusting the percent hybridizations of reference DNA and homologous unlabeled DNA to $100 \%$ and applying a corresponding correction to hybridizations with heterologous DNAs.

The thermal stability of reassociation duplexes was usually determined by a modification of the batch separation procedure involving stepwise increases in the temperature at which DNA was eluted from HA $(4,19) . T_{m(e)}$ is the temperature at which one-half of the DNA which reassociated at $65^{\circ} \mathrm{C}$ was eluted from HA. $\Delta T_{m(e)}$ is the difference between the $T_{m(e)}$ value for reassociated homologous DNA and $T_{m(e)}$ for reassociated heterologous DNA. For one label, a thermal binding index was calculated by dividing the relative hybridization value at $65^{\circ} \mathrm{C}$ into the relative hybridization value at $80^{\circ} \mathrm{C} \mathrm{(3).}$

Regeneration of HA. An adaptation of the procedure for preparing $\mathrm{HA}$ described by Bernardi (2) was used to regenerate used $\mathrm{HA}$. $\mathrm{NaOH}(0.1 \mathrm{M} ; 2$ liters) was added to wet-packed HA $(500 \mathrm{ml})$, mixed by inversion, and allowed to stand for $25 \mathrm{~min}$, and the supernatant was then decanted. This step was repeated. The HA was washed once with deionized distilled water (4 liters) by resuspending it, allowing it to settle, and decanting the supernatant liquid. PB (0.01 M; pH 6.8; 4 liters) was added, the suspension was mixed, HA was allowed to settle, and the PB was decanted. An additional 4 liters of 0.01 M PB was added, and the suspension was brought to a boil by placing the container in a water bath at $100^{\circ} \mathrm{C}$ and stirring continuously. The HA was allowed to settle, and the supernatant liquid was decanted. This step was repeated, but the suspension was held at $100^{\circ} \mathrm{C}$ for $5 \mathrm{~min}$. The $\mathrm{HA}$ was resuspended in two additional batches of buffer and brought to $100^{\circ} \mathrm{C}$ for $15 \mathrm{~min}$ in each batch. Finally, the HA was resuspended in 0.001 M PB (4 liters) held at $100^{\circ} \mathrm{C}$ for $15 \mathrm{~min}$ and stored in $0.001 \mathrm{M} P B$ at $4^{\circ} \mathrm{C}$ until required.

\section{RESULTS}

Nodulation and effectiveness. Nodulation and effectiveness (ability to fix atmospheric nitrogen) were tested for all of the $R$. trifolii strains on white clover and $T$. subterraneum $\mathrm{cv}$. Tallerook (Table 1). Strains NZP514 and WU290iii were already known to be nonnodulating variants, but CB782, WU290, and CC229 also failed to form nodules. On subterranean clover, CC2480a was ineffective, and NZP540, NZP560, and CC275e were more effective on the Tallarook cultivar than had been expected. Testing of the strains on T. subterraneum cv. Woogenellup confirmed the lack of nodules with WU290 and the noneffectiveness of CC2480a and showed that NZP540, NZP560, and CC275e were less effective on this cultivar. Later, CB782 and CC229 were confirmed as variants which did not nodulate their host species ( $T$. semipilosum and $T$. ambiguum, respectively).

The four $R$. leguminosarum strains formed effective nodules on $V$. hirsuta and also formed ineffective nodules on subterranean clover, but they did not nodulate white clover. Three of the four $R$. phaseoli strains were nonnodulating on $P$. vulgaris.

Homologies among related strains. Reference DNAs were prepared from two strains of $R$. trifolii (CC275e and TA1) and were reassociated with DNAs from other strains in the same cross-inoculation group and a few representative strains from two other cross-inoculation groups (Table 2). Some of the $R$. trifolii strains used had common features (Table 1), and their apparent similarities can be compared with their relative hybridization values.

Strains NZP5039 and NZP5117 were isolated from ineffective nodules on a legume indigenous to New Zealand, Clianthus puniceus, but both strains form effective nodules on white clover and thus appear to be $R$. trifolii. When DNAs 
TABLE 1. Strains of Rhizobium included in this study and their ability to nodulate and fix atmospheric nitrogen (effectiveness) on two species of Trifolium

\begin{tabular}{|c|c|c|c|c|}
\hline \multirow[b]{2}{*}{ Strain $^{a}$} & \multirow[b]{2}{*}{ Geographical origin } & \multicolumn{2}{|c|}{ Effectiveness on: ${ }^{b}$} & \multirow[b]{2}{*}{ Remarks } \\
\hline & & T. repens & $\begin{array}{l}\text { T. subterra- } \\
\text { neum cv. Talla- } \\
\text { rook }\end{array}$ & \\
\hline \multicolumn{5}{|l|}{ R. trifolii } \\
\hline CC275e & Australia & $\mathbf{E}$ & $\mathbf{E}^{\mathbf{c}}$ & $\begin{array}{l}\text { New Zealand standard inoculant } \\
\text { strain }\end{array}$ \\
\hline TA1 & Tasmania, Australia & $\mathbf{E}$ & $\mathbf{E}$ & $\begin{array}{l}\text { Australian and New Zealand stan- } \\
\text { dard inoculant strain }\end{array}$ \\
\hline TA2 & Tasmania, Australia & $\mathbf{E}$ & $\mathbf{E}$ & $\begin{array}{l}\text { Serologically related to, but not iden- } \\
\text { tical to, TA1 }\end{array}$ \\
\hline WU95 & West Australia & SE & $\mathbf{E}$ & Australian standard inoculant strain \\
\hline WU290 & West Australia & 0 & 0 & $\begin{array}{l}\text { Nonnodulating variant; serologically } \\
\text { identical to WU290iii }\end{array}$ \\
\hline WU290iii & West Australia & 0 & $\mathbf{0}$ & Nonnodulating variant of WU290 \\
\hline $\mathrm{CC} 2480 \mathrm{a}$ & Greece & I & $I^{r}$ & $\begin{array}{l}\text { Ineffective variant of Australian stan- } \\
\text { dard inoculant strain for subterra- } \\
\text { nean clover }\end{array}$ \\
\hline $\begin{array}{l}\text { NZP505/1 } \\
\text { (TLN3) }\end{array}$ & Japan & I & I & Isolated in Japan from $T$. lupinaster \\
\hline CB782 & Kenya & 0 & 0 & $\begin{array}{l}\text { Nonnodulating variant of the stan- } \\
\text { dard inoculant strain for } T \text {. semi- } \\
\text { pilosum }\end{array}$ \\
\hline NZP2 (K8) & The Netherlands & $\mathbf{E}$ & SE & Reported to be good on acid soils \\
\hline NZP1/6 & New Zealand & $\mathbf{E}$ & $\mathbf{E}$ & $\begin{array}{l}\text { Previous New Zealand standard ino- } \\
\text { culant strain }\end{array}$ \\
\hline UNZ29 & New Zealand & $\mathbf{E}$ & $\mathbf{E}$ & $\begin{array}{l}\text { Previous Australian standard strain; } \\
\text { same origin as NZP1/6 }\end{array}$ \\
\hline NZP514/1 & Te Anau, New Zealand & $\mathbf{E}$ & $\mathbf{E}$ & Isolated from subterranean clover \\
\hline NZP514 & Te Anau, New Zealand & 0 & 0 & Nonnodulating variant of $514 / 1$ \\
\hline $\begin{array}{l}\text { NZP540 } \\
\text { (PDDCC2666) }\end{array}$ & Otago, New Zealand & $\mathbf{E}$ & $\mathbf{E}$ & $\begin{array}{l}\text { Reisolated from plant trial inoculated } \\
\text { with PDDCC } 2153 \text { and serologi- } \\
\text { cally identical to this strain }\end{array}$ \\
\hline NZP549 & $\begin{array}{l}\text { Palmerston North, New } \\
\text { Zealand }\end{array}$ & SE & $\mathbf{E}$ & Isolated from Trifolium uniflorum \\
\hline NZP554 & $\begin{array}{l}\text { Palmerston North, New } \\
\text { Zealand }\end{array}$ & ME & $\mathbf{E}$ & Isolated from Trifolium pallescens \\
\hline $\begin{array}{l}\text { NZP560 } \\
\text { (PDDCC2153) }\end{array}$ & Otago, New Zealand & $\mathbf{E}$ & $\mathbf{E}^{d}$ & $\begin{array}{l}\text { New Zealand standard inoculant } \\
\text { strain }\end{array}$ \\
\hline NZP5039 & $\begin{array}{l}\text { Palmerston North, New } \\
\text { Zealand }\end{array}$ & $\mathbf{E}$ & I & $\begin{array}{l}\text { Isolated from ineffective nodules on } \\
\text { C. punicus but nodulates Trifolium } \\
\text { supp. }\end{array}$ \\
\hline NZP5117 & $\begin{array}{l}\text { Waikaremoana, } \\
\text { Zealand }\end{array}$ & $\mathbf{E}$ & I & $\begin{array}{l}\text { Isolated from ineffective nodules on } \\
\text { C. punicus but nodulates Trifolium } \\
\text { spp. }\end{array}$ \\
\hline SA3 & South Africa & I & I & Effective on $T$. africanum \\
\hline $\mathrm{CC} 227$ & Turkey & I & I & Effective on T. ambiguum \\
\hline CC229 & Turkey & 0 & 0 & $\begin{array}{l}\text { Nonnodulating variant of a strain iso- } \\
\text { lated from } T \text {. ambiguum }\end{array}$ \\
\hline CC231a & Turkey & I & I & Effective on $T$. ambiguum \\
\hline SU202 (Coryn) & Wales, United Kingdom & I & I & Standard ineffective strain \\
\hline NZP550/2 & United States & $\mathbf{E}$ & $\mathbf{E}$ & $\begin{array}{l}\text { Isolated from a mixed culture inocu- } \\
\text { lant for Trifoloium vesiculosum } \\
\text { from the United States }\end{array}$ \\
\hline $\mathrm{CC} 277 \mathrm{a}$ & $\begin{array}{l}\text { United States via Aus- } \\
\text { tralia }\end{array}$ & I & I & $\begin{array}{l}\text { Isolated from Trifolium dasyphyl- } \\
\text { lum, an alpine species from the } \\
\text { United States }\end{array}$ \\
\hline \multicolumn{5}{|l|}{ R. leguminosarum } \\
\hline SU391 & Australia & 0 & I & $\begin{array}{l}\text { Australian standard inoculant strain } \\
\text { for peas; effective on } V \text {. hirsuta }\end{array}$ \\
\hline TA101 & Tasmania, Australia & 0 & I & $\begin{array}{l}\text { Australian and New Zealand stan- } \\
\text { dard inoculant strain for peas and } \\
\text { vetches; effective on } V \text {. hirsuta }\end{array}$ \\
\hline
\end{tabular}


TABLE 1-continued

\begin{tabular}{|c|c|c|c|c|}
\hline \multirow[b]{2}{*}{ Strain $^{a}$} & \multirow[b]{2}{*}{ Geographical origin } & \multicolumn{2}{|c|}{ Effectiveness on: ${ }^{b}$} & \multirow[b]{2}{*}{ Remarks } \\
\hline & & T. repens & $\begin{array}{l}\text { T. subterra- } \\
\text { neum cv. Talla- } \\
\text { rook }\end{array}$ & \\
\hline NZP5225 & $\begin{array}{l}\text { Palmerston North, New } \\
\text { Zealand }\end{array}$ & 0 & I & Effective on $V$. hirsuta \\
\hline CB596 & United Kingdom & 0 & I & $\begin{array}{l}\text { From Rothamstead Experimental } \\
\text { Station; effective on } V \text {. hirsuta }\end{array}$ \\
\hline \multicolumn{5}{|l|}{ R. phaseoli } \\
\hline CC511 & Australia & & & $\begin{array}{l}\text { Nonnodulating variant of Australian } \\
\text { and New Zealand standard inocu- } \\
\text { lant strain for } P \text {. vulgaris }\end{array}$ \\
\hline NZP5097 & Lincoln, New Zealand & & & $\begin{array}{l}\text { Nonnodulating variant of strain iso- } \\
\text { lated from } P \text {. vulgaris }\end{array}$ \\
\hline NZP5459 & Lincoln, New Zealand & & & Effective on $P$. vulgaris \\
\hline CB971 & Phillipines & & & $\begin{array}{l}\text { Nonnodulating variant of Australian } \\
\text { and New Zealand standard inocu- } \\
\text { lant strain for } P \text {. vulgaris }\end{array}$ \\
\hline
\end{tabular}

${ }^{a}$ Alternative designations for the same strain are given in parentheses. Strain sources are denoted by letter prefixes as follows: CC, Division of Plant Industry, Commonwealth Scientific and Industrial Research Organization, Canberra City, Australia; CB, Division of Tropical Agronomy, Commonwealth Scientific and Industrial Research Organization, Cunningham Laboratory, St. Lucia, Australia; NZP, Applied Biochemistry Division, Department of Scientific and Industrial Research, Palmerston North, New Zealand; PDDCC, Plant Diseases Division, Department of Scientific and Industrial Research, Mont Albert, Auckland, New Zealand; SA, Microbiology Section, Plant Protection Research Institute, Department of Agricultural Technical Services, Pretoria, South Africa; SU, University of Sydney, Sydney, Australia; TA, Tasmanian Department of Agriculture, Hobart, Australia; UNZ, Plant Diseases Division, Department of Scientific and Industrial Research, Mont Albert, New Zealand (designated thus after transfer to Uraguay and Australia); WU, University of Western Australia, Nedlands, Australia.

${ }^{b}$ Effectiveness ratings: E, effective; ME, moderately effective; SE, slightly effective; I, ineffective; 0 , no nodules.

${ }^{c}$ Slightly effective on T. subterraneum cv. Woogenellup.

${ }^{d}$ Moderately effective on $T$. subterraneum cv. Woogenellup.

from these strains were reassociated with reference DNA from $R$. trifolii strain TA1, the relative hybridization values were 68 and $66 \%$, respectively, well within the range for $R$. trifolii strains, and confirmed that these strains were members of $\boldsymbol{R}$. trifolii. By contrast, NZP5106, a strain effective on $C$. puniceus, had earlier been found to give a relative hybridization value of $17 \%$ with reference DNA from strain TA1 (19).

Several of the strains compared are serologically related. Strains TA1 and TA2 are considered to be related but not identical. The difference between the relative hybridization values of the DNAs from these two strains with CC275e reference DNA is not statistically significant (65 and $70 \%)$, although the $\Delta T_{m(e)}$ values differ by $1.5^{\circ} \mathrm{C}$. However, when reference DNA from TA1 was used, relative hybridization with DNA from TA2 was $94 \%$, and a statistically significant difference was observed. This was associated with a $\Delta T_{m(e)}$ value of $1.3^{\circ} \mathrm{C}$.

Strain WU290 is a nonnodulating variant selected during this work from the original strain effective on T. subterraneum, and WU290ii is a nonnodulating variant selected in Australia.
Nonnodulating variants of WU290 are serologically identical (14). No statistically significant difference was detected between their relative hybridization values with either reference DNA.

Strain NZP540 was isolated from a field plot inoculated with NZP560. These strains were effective and serologically identical. They were not significantly different in base sequence homology with either reference strain. It was concluded that strains which were indistinguishable serologically were unlikely to show different relative hybridization or $\Delta T_{m(e)}$ values with independent reference DNAs, but partial serological differences can be reflected by differences in relative hybridization and $\Delta T_{m(e)}$ values, especially when reference DNA is prepared from one of the strains under consideration.

Strain NZP514 is a nonnodulating variant of an effective strain, NZP514/1. Relative hybridization values with reference DNA from TAl for NZP514 and NZP514/1 were 77 and $74 \%$, respectively. These values are not significantly different from one another. They indicate that the base sequence similarity of the DNAs from these strains with DNA from TA1 was unaf- 
TABLE 2. Relative hybridization of DNAs from strains of $R$. trifolii, $R$. leguminosarum, $R$. phaseoli, and Escherichia coli with reference DNAs from two strains of $R$. trifolii and one strain of $R$. phaseoli

\begin{tabular}{|c|c|c|c|c|c|c|c|c|}
\hline \multirow{4}{*}{$\begin{array}{l}\text { Source of unlabeled } \\
\text { DNA }^{u}\end{array}$} & \multicolumn{8}{|c|}{ Labeled reference DNA from: } \\
\hline & R. trifolii & $275 \mathrm{e}$ & R. trifolii & ral & & T.phas & eoli CC511 & \\
\hline & \multirow{2}{*}{$\begin{array}{l}\text { Relative hy- } \\
\text { bridization } \\
(\%)^{\text {h.c }}\end{array}$} & \multirow{2}{*}{$\begin{array}{l}\Delta T_{m(\text { e) }} \\
\left({ }^{\circ} \mathrm{C}\right)\end{array}$} & \multirow{2}{*}{$\begin{array}{l}\text { Relative hy- } \\
\text { bridization } \\
(\%)^{h, d}\end{array}$} & \multirow{2}{*}{$\begin{array}{l}\Delta T_{m(-)} \\
\left({ }^{\circ} \mathrm{C}\right)\end{array}$} & \multicolumn{2}{|c|}{$\begin{array}{c}\text { Relative hybridiza- } \\
\text { tion }^{h_{*}}\end{array}$} & \multirow{2}{*}{$\begin{array}{c}\text { Thermal } \\
\text { binding index }\end{array}$} & \multirow{2}{*}{$\begin{array}{l}\Delta T_{m+e} \\
\left({ }^{\circ} \mathrm{C}\right)\end{array}$} \\
\hline & & & & & $\begin{array}{c}\text { At } 65^{\circ} \mathrm{C} \\
(\%)\end{array}$ & $\begin{array}{l}\text { At } 80^{\circ} \mathrm{C} \\
\text { (\%) }\end{array}$ & & \\
\hline \multicolumn{9}{|l|}{$\overline{R . \text { trifolii }^{f}}$} \\
\hline CC275e & 100 & 0 & 60 & 7.5 & 48 & 22 & 0.5 & \\
\hline TA1 & 65 & 6.9 & 100 & 0 & 49 & 18 & 0.4 & \\
\hline TA2 & 70 & 5.4 & 94 & 1.3 & 52 & 19 & 0.4 & 8.4 \\
\hline WU95 & 74 & 1.9 & 73 & & 52 & 21 & 0.4 & \\
\hline WU290 & 80 & & 58 & & 42 & 9 & 0.2 & \\
\hline WU290iii & 75 & 4.9 & 57 & & 47 & 15 & 0.3 & \\
\hline $\mathrm{CC} 2480 \mathrm{a}$ & 71 & 3.7 & 70 & 4.1 & 57 & 25 & 0.4 & 7.1 \\
\hline NZP505/1 & 7 & & 12 & & 15 & 0 & 0.0 & \\
\hline CB782 $2^{h}$ & 45 & 10.6 & 45 & 10.0 & 46 & 8 & 0.2 & 10.4 \\
\hline NZP2 & 73 & 3.5 & 73 & & 50 & 19 & 0.4 & \\
\hline NZP1/6 & 74 & 3.6 & 87 & & 50 & 22 & 0.4 & \\
\hline UNZ29 & 66 & 7.0 & 83 & & 44 & 12 & 0.3 & \\
\hline NZP514/1 & 74 & 8.3 & 74 & & 54 & 20 & 0.4 & \\
\hline NZP514 & & & 77 & & 52 & 20 & 0.4 & \\
\hline NZP540 & 91 & 0.2 & 67 & & 52 & 19 & 0.4 & \\
\hline NZP549 & 82 & 1.2 & 58 & & 47 & 18 & 0.4 & \\
\hline NZP554 & 79 & & 49 & & 40 & 3 & 0.1 & \\
\hline NZP560 & 87 & 0.2 & 63 & & 46 & 12 & 0.3 & \\
\hline NZP5039 & & & 68 & & 51 & 20 & 0.4 & 7.9 \\
\hline NZP5117 & 81 & 2.4 & 66 & & 50 & 20 & 0.4 & \\
\hline SA3 & 60 & 7.5 & 56 & 7.0 & 54 & 27 & 0.5 & 6.5 \\
\hline $\mathrm{CC} 227^{i}$ & 74 & 11.8 & 71 & 6.0 & 54 & 16 & 0.3 & 9.3 \\
\hline $\mathrm{CC}^{229^{i}}$ & 73 & 3.1 & 72 & & 52 & 18 & 0.3 & \\
\hline CC231a ${ }^{i}$ & 66 & 4.5 & 69 & 5.9 & 55 & 19 & 0.4 & 9.2 \\
\hline SU202 & 81 & 0 & 72 & & 48 & 19 & 0.4 & 7.9 \\
\hline NZP550/2 & 62 & 8.3 & 53 & & 42 & 4 & 0.1 & 11.8 \\
\hline $\mathrm{CC} 277 \mathrm{a}$ & & & 65 & & 48 & 13 & 0.3 & 7.7 \\
\hline \multicolumn{9}{|l|}{ R. leguminosarum } \\
\hline SU391 & & & 59 & & 52 & 22 & 0.4 & \\
\hline TA101 & 71 & 5.5 & 67 & 4.5 & 51 & 16 & 0.3 & 8.9 \\
\hline NZP5225 & 74 & 4.6 & 90 & 1.8 & 55 & 21 & 0.4 & 7.3 \\
\hline CB596 & & & 71 & & 51 & 23 & 0.4 & \\
\hline \multicolumn{9}{|l|}{ R. phaseoli } \\
\hline CC511 & 43 & 8.4 & 46 & 8.5 & 100 & 100 & 1.0 & \\
\hline NZP5097 & 50 & 6.5 & 48 & 7.9 & 61 & 25 & 0.4 & 7.8 \\
\hline NZP5459 & & & 48 & & 52 & 19 & 0.4 & \\
\hline CB971 & & & 37 & & 44 & 18 & 0.4 & 10.5 \\
\hline Escherichia coli B & 0 & & 0 & & 0 & 0 & & \\
\hline
\end{tabular}

${ }^{a}$ Strains are listed in the same order as in Table 1.

${ }^{b}$ Each relative hybridization value is the mean of duplicate determinations for at least two hybridizations. Standard errors of the means with reference DNAs from $R$. trifolii CC275e, $R$. trifolii TA1, and $R$. phaseoli CC511 were \pm 1.7 (range \pm 0.3 to \pm 3.8 ), \pm 0.9 (range, \pm 0.3 to \pm 2.5 ), and \pm 0.8 (range \pm 0.3 to \pm 1.9 ), respectively.

"All hybridizations were at a $\mathrm{C}_{0} \mathrm{t}$ of 100 and $65^{\circ} \mathrm{C}$. The fraction reassociated with homologous DNA was $69 \%$. and the $T_{m(e)}$ was $91.2^{\circ} \mathrm{C}$.

${ }^{d}$ All hybridizations were at a $\mathrm{C}_{0} \mathrm{t}$ of 250 and $65^{\circ} \mathrm{C}$. The fraction reassociated with homologous DNA was $63 \%$, and the $T_{m(e)}$ was $91.6^{\circ} \mathrm{C}$.

${ }^{e}$ All hybridizations were at a $\mathrm{C}_{0} \mathrm{t}$ of 250 . The fractions reassociated with homologous DNA at 65 and $80^{\circ} \mathrm{C}$ were 83 and $67 \%$, respectively. The $T_{m(e)}$ for the fraction reassociated at $65^{\circ} \mathrm{C}$ was $91.9^{\circ} \mathrm{C}$.

${ }^{f}$ These strains are classified as $R$. trifolii, but some are members of distinct effectiveness subgroups within the genus Trifolium.

${ }^{g}$ Isolated from $T$. lupinaster.

${ }^{h}$ Isolated from T. semipilosum.

${ }^{i}$ Isolated from T. ambiguum. 
fected by loss of nodulating ability. Similarly, WU290 and WU290iii are nonnodulating variants of WU290 isolated independently, but there is no significant difference in their relationship with the two reference strains. All of these results suggest that loss of ability to form nodules on legume roots is associated with a change in DNA too small to affect overall base sequence homology.

Strain UNZ29 is considered to be the same strain as NZP1/6. The culture designated UNZ29 was maintained in Uruguay and Australia before being returned to New Zealand. Relative hybridization and $\Delta T_{m(e)}$ values with CC275e reference DNA indicate significant differences between the two cultures, but the difference between their relative hybridization values with DNA from TA1 was not significant.

Homology and plant specificity. Homology values for DNAs from 18 European clover rhizobia and CC275e reference DNA ranged from 60 to $91 \%$, with a mean of $75 \%$ (Table 2). When DNAs from 20 European clover rhizobia were compared with reference DNA from strain TA1, the homology values ranged from 49 to $94 \%$, with a mean of $68 \%$. Values for $\Delta T_{m(e)}$ ranged from 0 to $8.2^{\circ} \mathrm{C}$ with reference DNA from CC275e and from 1.3 to $7.0^{\circ} \mathrm{C}$ with reference DNA from TA1. These figures indicate considerable genetic variation among European clover rhizobia.

Table 2 lists three strains of rhizobia (CC227, CC229, and CC231a) derived from Caucasian clover (T. ambiguum). This species requires specific root nodule bacteria, and these bacteria do not effectively nodulate the common European clovers (Table 1); however, relative reassociation and $\Delta T_{m(e)}$ values for DNA from Caucasian clover strains and reference DNA from $R$. trifolii (CC275e or TA1) are generally of the same order as those with DNAs from other strains of $R$. trifolii. It is concluded that marked differences in plant specificity are not necessarily associated with more general genetic divergence in the rhizobia. Similarly, Table 2 lists four strains of $R$. leguminosarum (NZP5225, CB596, TA101, and SU391). The relative reassociation values for the DNAs from these organisms and the $\Delta T_{m(e)}$ values, where these are known, are of the same order as those between $R$. trifolii reference DNAs and DNAs from other strains of $R$. trifolii. Thus, base sequence similarity does not necessarily reflect plant specificity. Rhizobia from a common stock may effectively nodulate plant species from different genera.

Relative hybridization values of strain CB782 from T. semipilosum with CC275e and TA1 were both $45 \%$, and $\Delta T_{m(e)}$ values were 10.6 and $10.0^{\circ} \mathrm{C}$, respectively. In this case a difference in plant origin was associated with general genetic divergence from the clover reference strains. Again, relative hybridization values of strain NZP505/1 from Trifolium lupinaster with CC275e and TA1 were 7 and $12 \%$, respectively. Similar results were obtained with a second preparation of DNA from NZP505/1. Subsequently, DNA was prepared from an additional strain (NZP504) from $T$. lupinaster and an older stock culture (NZP505) from which the strain of NZP505/1 had been derived. These DNAs were reassociated at $65^{\circ} \mathrm{C}$ with reference DNA from CC275e. The relative reassociation value for NZP504 was $12 \%$, and that for NZP505 was $6 \%$. These values are well outside the range expected with $R$. trifolii and suggest that genetically distinct groups of bacteria may be identified among the rhizobia infecting plants in the genus Trifolium.

Table 2 also lists strains from $P$. vulgaris, the garden bean. These were included because $R$. phaseoli has sometimes been placed in the same species as rhizobia effective on clovers $(15,25$, 33). The relative hybridization values for DNAs from bean rhizobia and the two clover reference DNAs averaged $45 \%$ (range, 37 to $50 \%$ ), and $\Delta T_{m(e)}$ values averaged $7.8^{\circ} \mathrm{C}$ (range, 6.5 to $\left.8.5^{\circ} \mathrm{C}\right)$. Reference DNA prepared from $R$. phaseoli strain CC511 was reassociated with DNAs from 22 strains of $R$. trifolii. Relative hybridization values at $65^{\circ} \mathrm{C}$ averaged $49 \%$ (range, 40 to $57 \%$ ), and $\Delta T_{m(e)}$ values averaged $8.2^{\circ} \mathrm{C}$ (range, 6.5 to $11.8^{\circ} \mathrm{C}$ ). Relative hybridization values at $80^{\circ} \mathrm{C}$ averaged $17.1 \%$, and thermal binding indexes averaged 0.35 . Relative hybridization and $\Delta T_{m(e)}$ values were similar for the three strains from $T$. ambiguum and the four strains of $R$. leguminosarum. These results indicate the probable genetic divergence between $R$. phaseoli and $R$. trifolii or related strains, but the data also show that strain CC511 was not closely related to the other three strains of $R$. phaseoli tested.

Reference DNA from $R$. phaseoli strain CC511 and DNA from strain CB782 from $T$. semipilosum showed $46 \%$ reassociation and a $\Delta T_{m(e)}$ of $10.4^{\circ} \mathrm{C}$ at $65^{\circ} \mathrm{C}$. The thermal binding index was 0.2 . These results indicate that strain CB782 has diverged as much from $R$. phaseoli strain CC511 as it has from the $R$. trifolii reference strains. Similarly, the reassociation values for DNA from strain NZP505/1 and CC511 reference DNA indicated that this strain from $T$. lupinaster was no more closely related to $R$. phaseoli than to $R$. trifolii.

To summarize, the average relative hybridization values at $65^{\circ} \mathrm{C}$ were calculated for groups of strains compared with the clover reference strains (Fig. 1). Each group was identified by its 


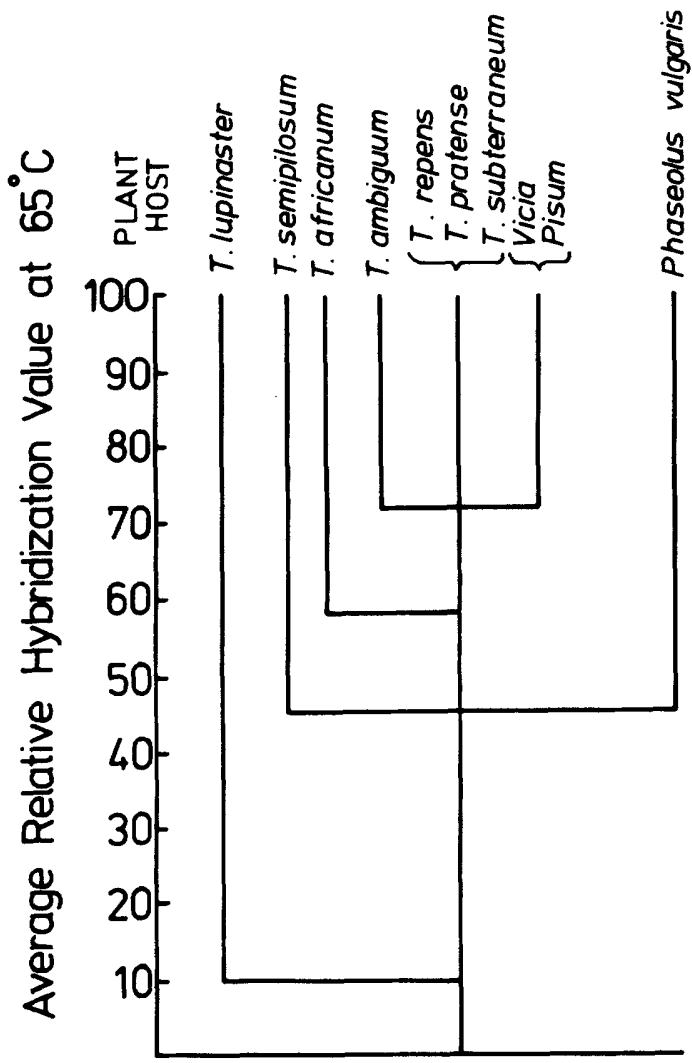

FIG. 1. Genetic relationships among Rhizobium strains from $T$. repens and $T$. subterraneum and rhizobia from species of Trifolium, Vicia, and Pisum and Phaseolus vulgaris.

plant specificity and was connected to the main stem by its average relative hybridization value. Strains from T. ambiguum, T. repens, T. subterraneum, Vicia, and Pisum form the main group. Strains from $P$. vulgaris are shown on a separate branch because none of the strains from clover species showed a closer relationship with bean strains than with clover reference strains. The strain from $T$. africanum is shown separately because, although its relationship to reference strains from European clovers is within the lower range for that cluster, it has a somewhat higher relationship with the bean reference strain than do most European clover strains. Strains from $T$. semipilosum and $T$. lupinaster are shown on separate branches because of their lack of homology with both clover and bean reference strains.

\section{DISCUSSION}

The classification of legume root-nodule bacteria in Bergey's Manual of Determinative Bacteriology, 8th ed. (22) includes six species, which are placed in one genus, Rhizobium. The fundamental characteristic of this genus is the ability to nodulate the roots of leguminous plants, but it is recognized that both effectiveness and nodulating capacity are readily lost in culture $(23,31)$. Our results with variants of $R$. trifolii NZP514 and WU290 indicate that loss of ability to nodulate had no significant effect on overall genetic homology with an independent Rhizobium reference strain. It is thought that the loss affected a relatively short DNA base sequence, and in other respects the variants remained similar to rhizobia recognizable by plant tests. If this is the case, additional criteria are necessary for the recognition of bacteria belonging to the genus Rhizobium. The limited results available suggest a correlation between DNA homology and serological relationships, a correlation which might be exploited for diagnostic purposes.

All bacteria which nodulate plants of the genus Trifolium are placed in one species, $R$. trifolii (22). Vincent (37) summarized previous work and recognized seven groups within this species. Strains were allocated to these groups according to their relative host specificity and effectiveness. Group 1 strains were most effective on $T$. repens and $T$.pratense; group 2 strains were effective on $T$. subterraneaum, $T$. incarnatum, and $T$. glomeratum; group 3 strains were effective on T. ambiguum; and strains of groups 4 through 7 were effective on individual central African species. We prepared reference DNAs from $R$. trifolii strains CC275e and TA1 (representative of groups 1 and 2 of Vincent, respectively). These DNAs were reassociated with DNAs from other clover rhizobia whose plant specificities were known. The relative hybridization values and the thermal stabilities of the reassociated DNAs do not support the subdivision of strains from European clovers into two subgroups. These strains seem to belong to one rather diverse genetic population. Relative hybridization values with reference DNAs from $R$. trifolii $\mathrm{CC} 274 \mathrm{e}$ and TA1 range from 60 to $91 \%$ and from 49 to $94 \%$, respectively. These values are comparable to those found in the related genus Agrobacterium (7), as is the thermal stability of the hybrid DNA (9), but the information is not sufficient to identify genetic races of $R$. trifolii, such as those found in the agrobacteria.

DNAs from rhizobia effective on $T$. ambig. uum reassociated with $R$. trifolii reference DNA to the same extent as they did with DNAs from European clover strains, but the thermal stability was low for one pair of DNAs (CC275e and CC227). If it is assumed that a $\Delta T_{m(e)}$ of $1^{\circ} \mathrm{C}$ is approximately equal to $1 \%$ divergence between the base sequences of DNAs from different sources $(24,35)$, a base sequence divergence of 
at least $12 \%$ is indicated between the reference DNA and DNA from CC227. By comparison, the mismatching in hybrids involving DNAs from other strains of $R$. trifolii and rhizobia from T. ambiguum did not exceed $8.2 \%$. This suggests that although some rhizobia effective on $T$. ambiguum probably belong to the same genetic population as the representatives of the first two subgroups of Vincent (37), the relationship between certain strains may be more remote than is indicated by the relative hybridization value at $65^{\circ} \mathrm{C}$.

Vincent (37) places rhizobia effective on African species of Trifolium in four additional effectiveness subgroups. Two strains of African origin were included in this study, SA3 from $T$. africanum and CB782 from $T$. semipilosum; these are representatives from groups 4 and 6 of Vincent, respectively. DNA hybridization indicated that both are more distantly related to the $R$. trifolii reference strains than are most strains from European clover species, T. ambiguum, and Vicia. Examination of a larger group of rhizobia from central African species of Trifolium may establish that they represent a sufficiently distinct genetic population to warrant designation as a separate species.

Strains of rhizobia effective on species of $\mathrm{Vi}$ cia, Pisum, Lathyrus, and Lens are designated $\boldsymbol{R}$. leguminosarum according to the classification in Bergey's Manual (22). Reassociation between DNAs from these strains and reference DNA from $R$. trifolii indicated that they belong to the same genetic population as the strains of $R$. trifolii and the rhizobia from $T$. ambiguum. A close relationship between $R$. trifolii and $R$. leguminosarum has been reported on several previous occasions $(8,13,15,19,33,38)$, and there seems to be little justification for continuing to maintain a distinction at the species level. Nevertheless, it is necessary to be able to distinguish between rhizobia whose plant specificities are different. It is suggested that rhizobia from $T$. repens, $T$. subterraneum, $T$. ambiguum, Vicia, and Pisum represent one genetic population and should be designated by one species name. The rules of nomenclature require that this name should be Rhizobium leguminosarum (Frank) Frank. Within the species, biovars could be identified according to the species name of the plant on which they nodulate most effectively, i.e., $R$. trifolii would become $R$. leguminosarum biovar T. repens, $T$. subterraneum, or $T$. ambiguum, and so on. This proposal reflects the genetic relationship and accepts the common usage among persons working with root nodule bacteria from legumes.

Reference DNA from $R$. phaseoli strain CC511 confirmed that rhizobia from bean spe- cies are genetically distinguishable from those from European clovers, T. ambiguum, Vicia, and Pisum. It also showed that although DNAs from rhizobia of beans and $T$. semipilosum had similar relative hybridization values with reference DNAs from European clover rhizobia, they probably represented distinct populations since the strain from $T$. semipilosum was no more closely related to the bean reference strain than to the clover reference strains. Several taxonomic studies have proposed combining $R$. phaseoli with $R$. trifolii and $R$. leguminosarum to form a single species for fast-growing, acidproducing rhizobia $(8,15,33)$, but DNA homology indicated that $R$. phaseoli is not as closely related to $R$. leguminosarum as $R$. trifolii is (13). Our results agree with this conclusion.

The average relationships among the strains discussed in this paper (Fig. 1) indicate that bacteria with specialized plant effectiveness may gain this function without loss of genetic similarity to other bacteria whose plant specificity is different. There are also cases where different plant specificities are associated with varying levels of genetic divergence. The first observation is at variance with the hypothesis of "symbio-taxonomy" proposed by Norris $(28,29)$. This suggests that as a legume evolves to fit a specialized ecological niche, its root nodule bacteria also evolve and tend to become specific for the new species of legume. Evolutionarily advanced legumes would be nodulated by genetically specialized bacteria, whereas legumes which have remained similar to the ancestral form would be nodulated by genetically unspecialized bacteria capable of nodulating a wider variety of legume species. Trifolium is considered an evolutionarily advanced genus $(28,29)$ and should be nodulated by distinct bacterial populations genetically selected as each symbiotic association evolved. These populations should show considerable genetic divergence from one another and from other legume root nodule bacteria. Our results indicate that rhizobia from $T$. lupinaster and $T$. semipilosum show the expected genetic divergence, but there is little evidence of it among strains in the $R$. trifolii- $R$. leguminosarum cluster, although some of these strains exhibit comparable symbiotic specialization.

An alternative explanation for these observations may be based on the existence of plasmids in Rhizobium (30,32, 34, 40). Evidence that plant specificity in Rhizobium is a plasmidborne character has accumulated over several years $(5,11,18,30)$, and high-frequency transfer of nodulating ability from $R$. leguminosarum to $R$. trifolii, $R$. phaseoli, and a member of the cowpea miscellany has been demonstrated recently (21). It seems likely that specific plasmids 
confer plant specificity on basically similar strains of bacteria and thus provide an alternative mechanism for the acquisition of plant specificity which does not require evolutionary specialization and consequent genetic divergence.

\section{ACKNOWLEDGMENTS}

We thank the following for supplying Rhizobium strains: J. Brockwell (strains CC227, CC229, CC231a, CC277a); R. A. Date (strains CC511, SU391, TA2, TA101); A. Hastings (strains CC275e, PDDCC2153, PDDCC2666); the late D. 0. Norris (strains CB596, CB782, CB971); C. A. Parker (strains SU202, TA1, UNZ29, WU95, WU290); R. J. Roughley (strains CC248a, WU290iii); B. W. Strijdom (strain SA3); and I. Watanabe (strains 505/1, 504). We also thank C. E. Pankhurst, Applied Biochemistry Division, Department of Scientific and Industrial Research, Palmerston North, New Zealand, for unpublished serological information and $R$. Tucker and C. P. Liddane for technical assistance.

We thank the Department of Scientific and Industrial Research and the University Grants Committee for financial support.

\section{REPRINT REQUESTS}

Address reprint requests to: Dr. B. D. W. Jarvis, Department of Microbiology and Genetics, Massey University, Palmerston North, New Zealand.

\section{LITERATURE CITED}

1. Abelson, J., and C. A. Thomas, Jr. 1966. The anatomy of the T5 bacteriophage DNA molecule. J. Mol. Biol. 18:262-291.

2. Bernardi, G. 1971. Chromatography of nucleic acids on hydroxyapatite columns. Methods Enzymol. 21D:95139.

3. Brenner, D. J., G. R. Fanning, K. E. Johnson, R. V. Citarella, and C. Falkow. 1969. Polynucleotide sequence relationships among members of Enterobacteriaceae. J. Bacteriol. 98:637-650.

4. Brenner, D. J., G. R. Fanning, A. V. Rake, and K. A. Johnson. 1969. Batch procedure for thermal elution of DNA from hydroxyapatite. Anal. Biochem. 28:447-459.

5. Brill, W. J. 1974. Genetics of $\mathrm{N}_{2}$-fixing organisms, p. 640660. In A. Quispel (ed.), The biology of nitrogen fixation. North Holland Publishing Co., Amsterdam, The Netherlands.

6. Britten, R. J., M. Pavich, and J. A. Smith. 1970. A new method for DNA purification. Carnegie Inst. Washington Yearb. 68:400-402.

7. De Ley, J. 1974. Phylogeny of procaryotes. Taxon 23: 291-300.

8. De Ley, J., and A. Rassel. 1965. DNA base composition, flagellation, and taxonomy of the genus Rhizobium. J. Gen. Microbiol. 41:85-91.

9. De Ley, J., R. Tijtgat, J. De Smedt, and M. Michiels. 1973. Thermal stability of DNA:DNA hybrids within the genus Agrobacterium. J. Gen. Microbiol. 78:241252.

10. Dixon, R. O. D. 1969. Rhizobia with particular reference to relationships with host plants. Annu. Rev. Microbiol. 23:137-158.

11. Dunican, L. K., and F. C. Cannon. 1971. The genetic control of symbiotic properties in Rhizobium - evidence for plasmid control. Plant Soil 1971(Special Volume): 73-79.

12. Fred, E. B., I. L. Baldwin, and E. McCoy. 1932. Root nodule bacteria and leguminous plants, University of Wisconsin Studies of Science no. 5. University of Wisconsin, Madison.

13. Gibbons, A. M., and K. F. Gregory. 1972. Relatedness among Rhizobium and Agrobacterium species deter- mined by three methods of nucleic acid hybridization. J. Bacteriol. 111:129-141.

14. Gibson, A. R., R. A. Date, J. A. Ireland, and J. Brockwell. 1976. A comparison of competitiveness and persistence amongst five strains of Rhizobium trifolii. Soil Biol. Biochem. 8:395-401.

15. Graham, P. H. 1964. The application of computer techniques to the taxonomy of the root-nodule bacteria of legumes. J. Gen. Microbiol. 36:511-517.

16. Graham, P. H. 1976. Identification and classification of root nodule bacteria, p. 99-112. In P. S. Nutman (ed.), Symbiotic nitrogen fixation in plants. Cambridge University Press, Cambridge, England.

17. Heberlein, G. T., J. De Ley, and R. Tijtgat. 1967. Deoxyribonucleic acid homology and taxonomy of Agrobacterium, Rhizobium, and Chromobacterium. J. Bacteriol. 94:116-124.

18. Higasti, S. 1967. Transfer of clover infectivity of Rhizobium trifolii to Rhizobium phaseoli as mediated by an episomic factor. J. Gen. Appl. Microbiol. 13:391-403.

19. Jarvis, B. D. W., T. S. MacLean, I. G. C. Robertson, and G. R. Fanning. 1977. Phenetic similarity and DNA base sequence homology of root nodule bacteria from New Zealand native legumes and Rhizobium strains from agricultural plants. N.Z. J. Agric. Res. 20:235-248.

20. Johnston, A. W. B., and J. E. Beringer. 1977. Genetic hybridization of root-nodule bacteria (Rhizobium), p. 81-90. In A. Hollaender (ed.), Genetic engineering for nitrogen fixation. Plenum Press, New York.

21. Johnston, A. W. B., J. L. Beynon, A. V. BuchananWollaston, S. M. Setchell, P. R. Hirsch, and J. E. Beringer. 1978. High frequency transfer for nodulating ability between strains and species of Rhizobium. Nature (London) 276:634-636.

22. Jordan, D. C., and O. N. Allen. 1974. Family III. Rhizobiaceae Conn, 1938, p. 261-264. In R. E. Buchanan and N. E. Gibbons (ed.), Bergey's manual of determinative bacteriology, 8 th ed. The Williams \& Wilkins Co., Baltimore.

23. Labandera, C. A., and J. M. Vincent. 1975. Loss of symbiotic capacity in commercially useful strains of Rhizobium trifolii. J. Appl. Bacteriol. 39:209-211.

24. Laird, C. D., B. L. McConaughy, and B. J. McCarthy. 1968. On the rate of fixation of nucleotide substitutions in evolution. Nature (London) 224:149-154.

25. Moffett, M. L., and R. R. Colwell. 1968. Adansonian analysis of the Rhizobiaceae. J. Gen. Microbiol. 51: 245-266.

26. Moustafa, E., and R. M. Greenwood. 1967. Esterase and phosphatase isoenzymes in rhizobia and rhizobial bacteroids in relation to strain effectiveness and proportion of nodule tissue in Lotus. N. Z. J. Sci. 10:54855.

27. Norris, D. F. 1965. Acid production by Rhizobium, a unifying concept. Plant Soil 22:143-166.

28. Norris, D. O. 1965. Rhizobium relationships in legumes, p. 1087-1092. In Z. Martins (ed.), Proceedings of the 9th International Grassland Congress, Sao Paulo, vol. 2. Edicoes Limitada, Sao Paulo, Brazil.

29. Norris, D. O., and L. "tMannetje. 1964. The symbiotic specialization of African Trifolium spp. in relation to their taxonomy and their agronomic use. East Afr. Agric. For. J. 24:214-235.

30. Nutti, M. P., A. M. Ledeboer, A. A. Lepidi, and R. A. Schilperoort. 1977. Large plasmids in different $R h i$ zobium species. J. Gen. Microbiol. 100:241-248.

31. Roughley, R. J. 1976. The production of high quality inoculants and their contribution to legume yield, $\mathrm{p}$. 125-136. In P. S. Nutman (ed.), Symbiotic nitrogen fixation in plants. Cambridge University Press, Cambridge, England.

32. Sutton, W. D. 1974. Some features of the DNA of Rhizobium bacteroids and bacteria. Biochim. Biophys. Acta 366:1-10. 
33. 'tMannetje, L. 1967. A reexamination of the taxonomy of the genus Rhizobium and related genera using numerical analysis. Antonie van Leeuwenhoek J. Microbiol. Serol. 33:477-491.

34. Tshitenge, G., N. Luyindula, P. F. Lurquin, and L. Ledoux. 1975. Plasmid deoxyribonucleic acid in Rhizobium vigna and Rhizobium trifolii. Biochim. Biophys. Acta 414:357-361.

35. Ullman, J. S., and B. J. McCarthy. 1973. The relationship between mismatched base pairs and the thermal stability of DNA duplexes. I. Effects of depurination and chain scission. Biochim. Biophys. Acta 294:405415 .

36. Vincent, J. M. 1970. A manual for the practical study of root nodule bacteria. Blackwell Scientific Publications,
Oxford, England.

37. Vincent, J. M. 1974. Root-nodule symbioses with $R$ hizobium, p. 266-341. In A. Quispel (ed.), The biology of nitrogen fixation. North Holland Publishing Co., Amsterdam, The Netherlands.

38. White, L. O. 1972. The taxonomy of the crown-gall organism Agrobacterium tumefaciens and its relationship to rhizobia and other agrobacteria. J. Gen. Microbiol. 72:565-574.

39. Wilson, J. K. 1944. Over five hundred reasons for abandoning the cross-inoculation groups of legumes. Soil Sci. 58:61-69.

40. Zurkowski, W., and Z. Lorkiewicz. 1976. Plasmid deoxyribonucleic acid in Rhizobium trifolii. J. Bacteriol. 128:481-484. 